\title{
Effectiveness of Bank Rate Instrument in Pakistan
}

\section{UMER Chapra*}

On January 15, 1959, bank rate was raised in Pakistan from its traditional level of 3 per cent to 4 per cent. This paper examines the effect of this rise of one percentage point in the bank rate on the borrowings of scheduled banks from the State Bank, their reserves, their lending rates, the supply of their credit, and the allocation of their credit among various sectors of the economy. This is done by comparing the values of certain relevant variables primarily in the year before the bank-rate change (1958) and the year after the bank-rate change (1959). From this examination of a single experience in Pakistan, it is not desired to prove that the bank rate would be effective or ineffective in future. It would, however, be unwise to ignore this bit of historical evidence in the country. The assessment will certainly give some idea of what to expect in future in comparable circumstances.

A rise in bank rate may be effective in curtailing scheduled bank credit in two different ways. First, it may be an effective way of announcing to both the banks and the public the direction of State Bank policy. Scheduled banks may become cautious as a result of this, and may, therefore, refuse to lend as much as previously at a given rate of interest. Second, a higher bank rate would make it costlier for scheduled banks to borrow from the State Bank. Scheduled banks may maintain relatively higher reserves after an increase in the bank rate because they know that in the event they have to borrow from the State Bank, it will be at a higher rate. However, bank rate would become a penalty rate only if the scheduled banks do not have excess reserves, need to borrow from the State Bank, and the bank rate exceeds the rate charged by scheduled banks.

Such an increase in the cost of scheduled bank borrowing might normally lead to an equal increase in market rates of interest unless the demand curve for scheduled bank loans moves to the left due to some exogenous factors. But if the marginal efficiency of investment is very high, as is generally believed to be the case in certain sectors of the economy of Pakistan (for example, large-scale industries, import and export business and whole-

*Dr. Chapra is Senior Economist in the Institute of Development Economics. This paper was a part of his Ph.D. dissertion presented to the University of Minnesota. He and Dr. Fenry Bruton, Dr. Richard Porter and Mr. S. U. Khan of the Institute for suggestions to give this final shape to the paper. Errors that still remain are the sole responsibility of the author. 
sale trade) ${ }^{1}$ then a small rise in the bank rate and the market rates of interest may have only a negligible effect on the borrowings of these sectors from the scheduled banks. This paper will, therefore, be mainly concerned with the supply and not the demand side of scheduled bank credit.

Scheduled bank borrowings from the State Bank declined by Rs. 42.6 million in 1959 from their level in $1958^{2}$. Was this due to the increase in the bank rate? This decline in scheduled bank borrowings could also be due to an increase in scheduled bank reserves which are affected by a number of factors.

Table I shows that the gross reserves of scheduled banks increased in 1959 by a monthly average of Rs. 54.3 million. Thus, the reserves of scheduled banks increased by more than the decline in their borrowings. Increase in the bank rate may, therefore, have been only a minor factor in the decline in scheduled bank borrowings from the State Bank. Borrowings may have gone down because reserves increased due to several factors the contribution of each of which can be seen from Table 1 .

The increase in the bank rate was followed by a rise in the lending rates of scheduled banks, but the rise came about gradually. The weighted average rate of interest charged by scheduled banks to the private sector rose from 4.21 per cent in December 1958 to 4.96 per cent in June 1959 and to 5.14 per cent in December $1959^{3}$ and June 1960 . There was, thus, a gradual rise of just under one percentage point in the lending rates of banks. The State Bank in its annual report for 1958-59 ascribes this rise in the interest rates to the bank rate, saying: "The lead of the State Bank was followed by other institutions and deposit rates and advance rates of commercial banks went up" 4 .

The main concern of this paper, however, is what happened to bank credit extended to the private and the government sectors in 1959 relative to 1958. For determining this, it is necessary to have seasonally-adjusted data of scheduled bank credit to the private and the government sectors during the 12 months of 1958 and 1959. But such data are not published

1According to the Planning Commission, marginal efficiency of investments is as high as $\mathbf{3 0}$ per cent in large-scale industries in Pakistan. No evidence has been given by the Planning Commission for this. See, p. 77, para 101, Second Five Year Plan, 1960-65. (Karachi: Manager of Publications, Government of Pakistan, 1960).

2Based on data from the State Bank of Pakistan, State Bank Bulletins.

${ }^{3}$ R. C. Porter, "Monetary Policy in the Economic Development of Pakistan" (cyclostyled paper read at the Businessmen's Seminar, Lahore, November 1961), p. 3.

4State Bank of Pakistan, Annual Report, 1958-59. (Karachi: State Bank of Pakistan, September 1959), p. 34. 


\section{TABLE I}

\section{FACTORS CHANGING SCHEDULED BANK RESERVES IN \\ PAKISTAN IN THE YEAR 1959}

Increase in currency outside the State Bank ${ }^{2} \quad \ldots$

$\frac{\text { (in million rupees) }}{++}$

Increase in government and other deposits at the State Bank (excluding deposits of scheduled banks)

$$
\cdots
$$$$
\cdots
$$$$
\cdots
$$

Increase in gold, foreign assets and balances held outside Pakistan $^{\text {b ... }}$

$$
\text { .. } \quad \cdots
$$

Decrease in government obligations ${ }^{c}$

Increase in State Bank investments in government and foreign securities $\quad \ldots \quad \ldots$

Decrease in other assets (net of other liabilities)d

\section{2} Total ...

\begin{tabular}{r|r}
18.2 & \\
\hline 266.6 & 26.1 \\
\hline
\end{tabular}

Gross increase in reserves (266.6-212.3)

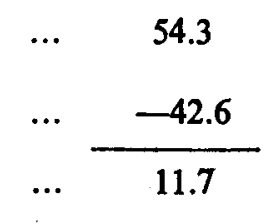

Less borrowings from the State Bank

Net increase in scbeduled bank reserves

Table is constructed from: (1) the balance sheets of both the Issue and the Banking Departments of the State Bank of Pakistan; $(\dot{z})$ the consolidated position of scheduled banks; and, (3) treasury currency. Based on data published in State Bank of Pakistan, State Bank Bulletins Data represent increases or decreases in annual averages of figures on last Friday of each month in 1959 over those in 1958. Bank.

a. Includes State Bank notes outstanding and treasury currency outside the State

b. Includes assets held with the Reserve Bank of India.

c- Includes: domestic assets held in the Issue Department; government treasury bills; provincial government debtor balances; loans and advances to governments; and treasury currency.

d. Includes: loans and advances other than those to the scheduled banks, other assets, less bills payable and capital and reserves and "other" liabilities. 
for Pakistan. Therefore, we have constructed our own estimates (Table II and Graph 1). There was a downward trend in scheduled bank credit to the private sector after October $1958^{5}$. This trend continued through January 1959, the month after the bank-rate change. Thereafter, the credit to the private sector started to expand; and, in December 1959, it was at a rate higher than the peak of 1958 . Total credit in 1959 was 4 per cent higher than the total in 1958 (Table III and Graph 2). Though credit increased in 1959 , the rate of increase of credit certainly dropped, because the average rate of increase of credit during the calendar years from 1954 to 1958 was 12 per cent per annum and it was only 4 per cent in 1959 (Table III).

However, although the rate of increase of bank credit to the private sector declined in 1959 from its previous level, the rate of increase of total scheduled bank credit to the government as well as the private sector remained 11 per cent as it was in the previous few years (Table III). This is because the rate of increase of bank credit to the government sector increased from an average of 10 per cent per annum from 1954-58 to 17 per cent in 1959. There was, thus, a shift in scheduled bank credit from the private sector to the government sector in 1959. Relatively more credit was extended to the government sector and relatively less to the private sector.

Was this shift in credit due to change in the bank rate? The average rate of interest on private loans as stated earlier was 5.14 per cent in 1959 . This evidently was higher than the bank rate in that year. The weighted average yield was 3.2 per cent on central government securities and 3.6 per cent on provincial government securities ${ }^{6}$. The yield on government securities was, therefore, lower than the bank rate and the yield to scheduled banks on private loans in 1959. The shift in bank credit was, therefore, not due to the yield on government securities becoming greater than the return to banks on loans to the private sector. It was probably due to reduction in private demand for credit? ${ }^{7}$. It may not be wrong to conclude that the bank rate was instrumental, if at all, to a very minor extent in bringing about the decline in the rate of increase of scheduled bank credit to the private sector.

This decline in private demand for credit also explains why the scheduled banks had positive free reserves ${ }^{8}$ in 1959 against their tradition of negative

5. In October 1958, martial law was imposed in Pakistan.

6. Figures based on data from State Bank of Pakistan, State Bank Bulletins.

7. According to M. Haq and K. Khanam, demand for credit has determined the expansion of bank credit in Pakistan throughout 1951-60. See, M. Haq and K. Khanam, Deficit Financing in Pakistan; 1951-60. (Karachi: Institute of Development Economics, 1961), p. 21.

8. Free reserves=excess reserves scheduled banks minus their borrowings from the State Bank. 
TABLE II

SCHEDULED BAYK CREDIT TO PRIVATE SECTOR AND INVESTMENTS IN GOVERNMENT SECURITIES, 1958 AND 1959

(in million rupees)

\begin{tabular}{|c|c|c|c|c|c|c|c|c|c|c|c|c|}
\hline \multirow{2}{*}{\multicolumn{2}{|c|}{ Months }} & & \multicolumn{5}{|c|}{ Credit to private sectora } & \multicolumn{5}{|c|}{ Investments in Government securitiesb } \\
\hline & & & \multicolumn{2}{|c|}{ Unadjusted } & \multirow[t]{2}{*}{ S.A.F.c } & \multicolumn{2}{|c|}{$\begin{array}{l}\text { Seasonally } \\
\text { adjusted }\end{array}$} & \multicolumn{2}{|c|}{ Unadjusted } & \multirow[t]{2}{*}{ S.A.F.c } & \multicolumn{2}{|c|}{$\begin{array}{l}\text { Seasonally } \\
\text { adjusted }\end{array}$} \\
\hline & & & 1958 & 1959 & & 1958 & 1959 & 1958 & 1959 & & 1958 & 1959 \\
\hline $\begin{array}{l}\text { January } \\
\text { February } \\
\text { March } \\
\text { April } \\
\text { May } \\
\text { June } \\
\text { July } \\
\text { August } \\
\text { September } \\
\text { October } \\
\text { November } \\
\text { December }\end{array}$ & $\begin{array}{l}\ldots \\
\cdots \\
\cdots \\
\cdots \\
\cdots \\
\cdots \\
\cdots \\
\cdots \\
\cdots \\
\cdots \\
\cdots\end{array}$ & $\begin{array}{l}\cdots \\
\cdots \\
\cdots \\
\cdots \\
\cdots \\
\cdots \\
\cdots \\
\cdots \\
\cdots \\
\cdots \\
\cdots\end{array}$ & $\begin{array}{l}1,382 \\
1,351 \\
1,327 \\
1,273 \\
1,235 \\
1,255 \\
1,255 \\
1,992 \\
1,356 \\
1,432 \\
1,481 \\
1,489\end{array}$ & $\begin{array}{l}1,425 \\
1,421 \\
1,423 \\
1,361 \\
1,272 \\
1,333 \\
1,370 \\
1,400 \\
1,355 \\
1,367 \\
1,489 \\
1,651\end{array}$ & $\begin{array}{r}110 \\
109 \\
106 \\
100 \\
96 \\
93 \\
91 \\
93 \\
93 \\
97 \\
104 \\
108\end{array}$ & $\begin{array}{l}1,256 \\
1,239 \\
1,252 \\
1,273 \\
1,286 \\
1,349 \\
1,379 \\
1,389 \\
1,458 \\
1,476 \\
1,424 \\
1,379\end{array}$ & $\begin{array}{l}1,295 \\
1,304 \\
1,342 \\
1,361 \\
1,325 \\
1,433 \\
1,505 \\
1,505 \\
1,457 \\
1,407 \\
1,432 \\
1,528\end{array}$ & $\begin{array}{r}918 \\
917 \\
929 \\
972 \\
1,007 \\
981 \\
959 \\
958 \\
993 \\
1,021 \\
1,032 \\
1,016\end{array}$ & $\begin{array}{l}1,038 \\
1,031 \\
1,039 \\
1,048 \\
1,081 \\
1,094 \\
1,206 \\
1,214 \\
1,202 \\
1,194 \\
1,236 \\
1,241\end{array}$ & $\begin{array}{r}99 \\
98 \\
98 \\
98 \\
96 \\
97 \\
103 \\
103 \\
104 \\
102 \\
101 \\
103\end{array}$ & $\begin{array}{r}927 \\
938 \\
948 \\
1,013 \\
1,049 \\
1,011 \\
931 \\
930 \\
955 \\
1,001 \\
1,022 \\
986\end{array}$ & $\begin{array}{l}1,048 \\
1,052 \\
1,060 \\
1,092 \\
1,126 \\
1,128 \\
1,171 \\
1,179 \\
1,156 \\
1,171 \\
1,224 \\
1,205\end{array}$ \\
\hline Average fo & months & $\therefore$ & 1,344 & 1,406 & 100 & 1,347 & 1,408 & 978 & 1,135 & 100 & 976 & 1,134 \\
\hline
\end{tabular}

a. Scheduled bank credit to private sector: unadjusted data are figures on the last Friday of each month obtained from State Bank Bulletins; includes advances, bills purchased and discounted, and investments in private securities; seasonally-adjusted figures are obtained on the basis of seasonal adjustment factors explained in footnote $c$.

b. Investments in government securities: unadjusted data obtained from State Bank Bulletins; include investments in both central and provincial government securities.

c. S.A.F. = seasonal adjustment factors:

(1) Credit to private sector-seasonal adjustment factors were obtained by taking moving averages centred at the seventh month of data from July 1954 to May 1960. This gave moving average for five years from January 1955 to December 1959 . Ratios of moving averages to original values were obtained for the respective months. A simple average was then obtained of the different ratios for the same month. These averages were thereafter adjusted for level so as to obtain a total of 1,200 for the 12 months. These adjusted averages are the seasonal adjustment factors as given in the Table.

(2) Investments in government securities-same procedure was adopted but the moving averages were obtained for the period between July 1954 and May 1958, thus giving averages for only three years. Smaller number of years was taken in this case because the seasonal fluctuations were not very wide. 


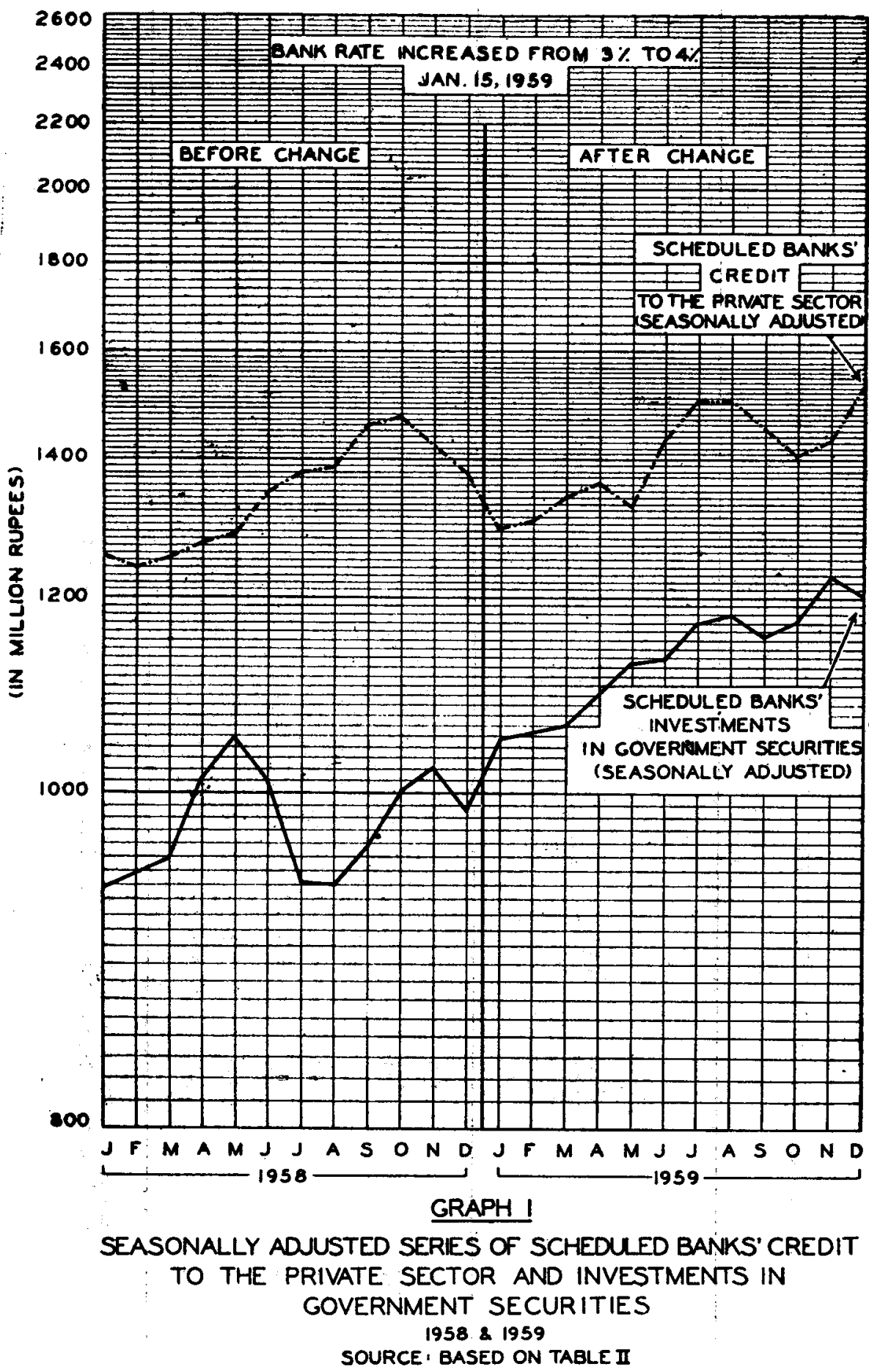


TABLE III

SCHEDULED BANK CREDIT TO PRIVATE SECTOR AND INVESTMENTS IN GOVERNMENT SECURITIES ^, 1954-1960

(Averages of 12 months of the Calendar year)

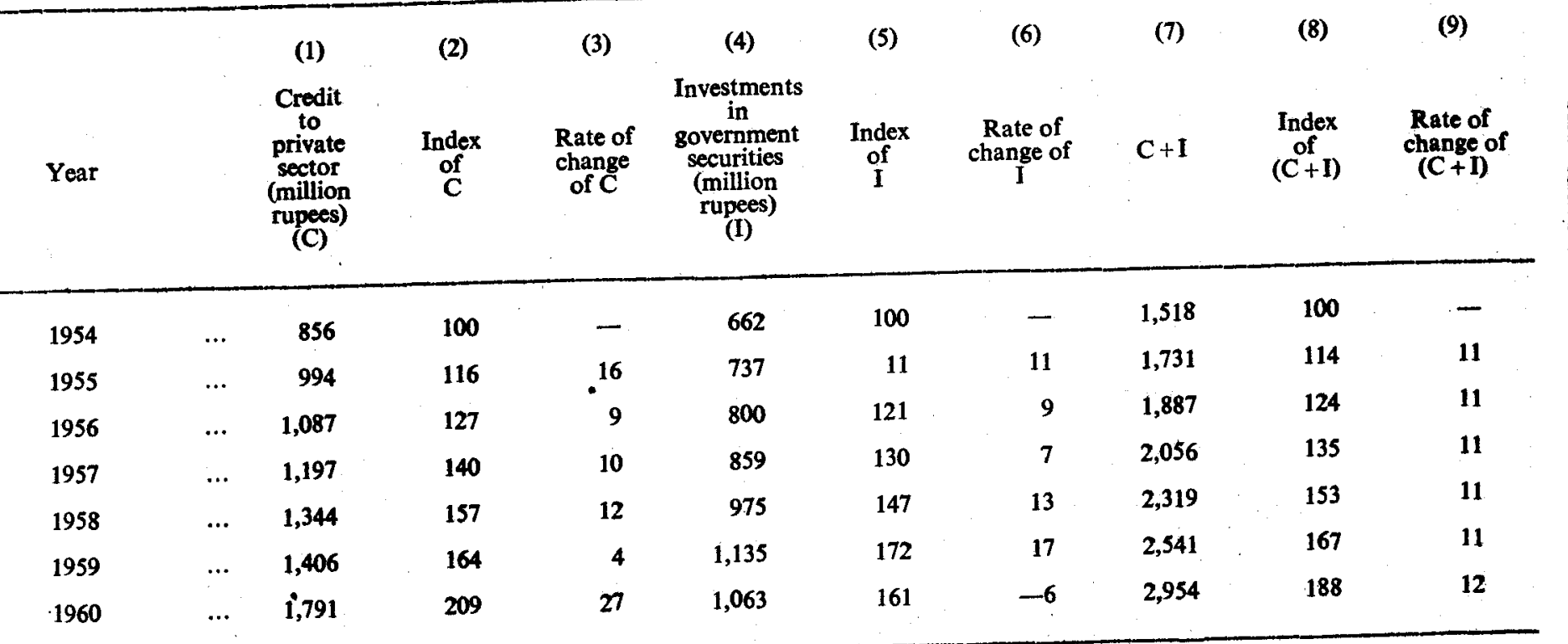

我

a. Includes both provincial and central government securities.

Includes both provincial and central government securities. 


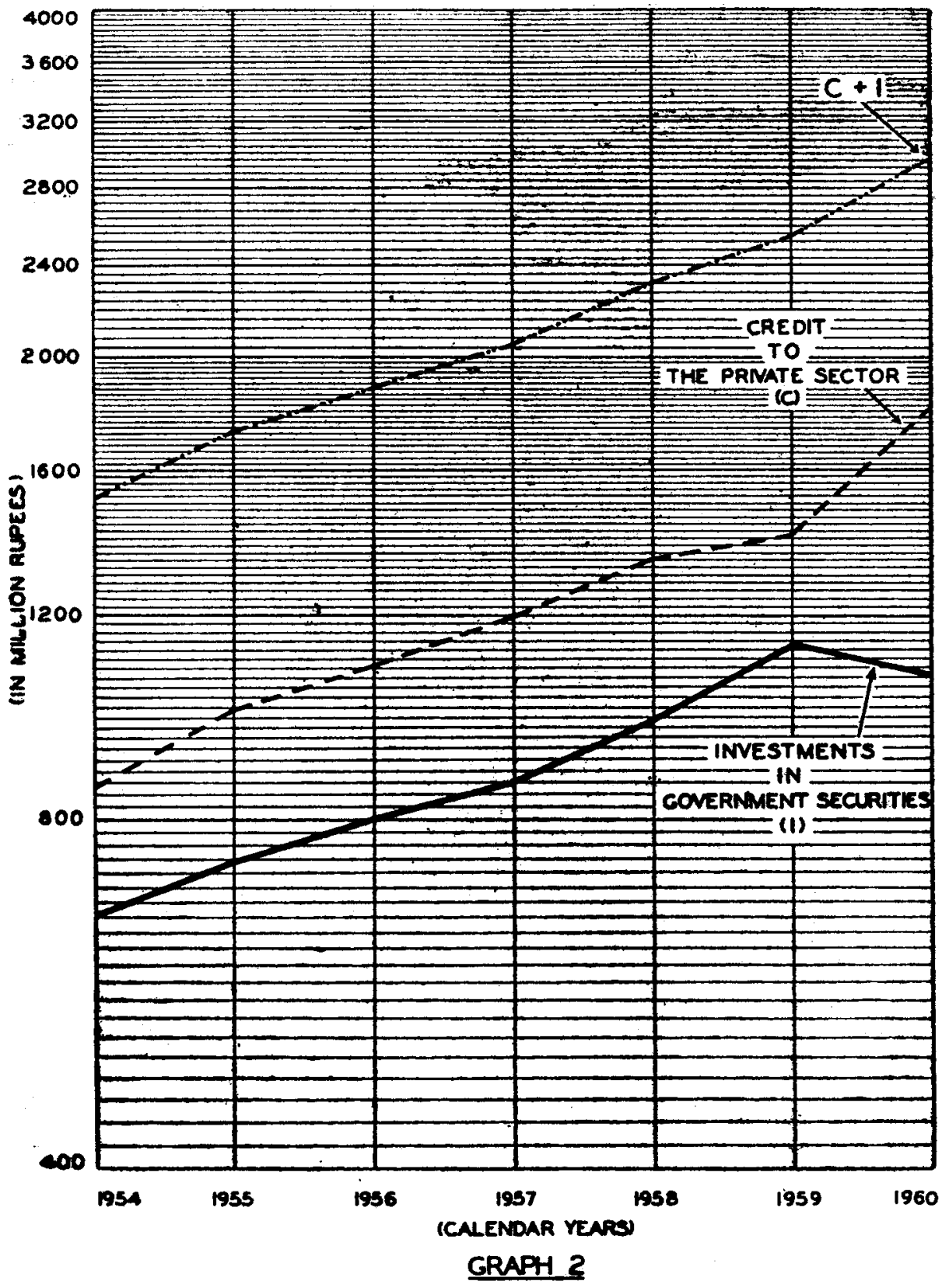

SCHEDURED BANKS' CREDIT TO PRIVATE SECTOR AND INVESTMENTS IN GOVERNMENT SECURITIIES

$1954-1960$

SOURCE : BASED ON TABLE II 
free reserves (Table IV). In 1959, scheduled banks had positive free reserves to the extent of .07 per cent of their demand and time liabilities subject to reserve requirements against average negative free reserves of 1.3 per cent from 1954 through 1958. In 1959, it was not profitable for banks to borrow from the State Bank and invest in government securities because the weighted average yield on government securities was lower than the bank rate. As stated earlier, the weighted average yield was 3.2 per cent on central government securities and 3.6 per cent on provincial government securities. The yield on private loans was certainly greater than the bank rate as mentioned earlier, and the banks could have profited by lending more to the private sector on the basis of their positive free reserves and also by borrowing more from the State Bank. But the demand for credit by the private sector had declined as shown above. Another evidence for the decline in private demand for credit is that the rates of scheduled bank lending to the private sector did not rise fast enough in response to the increase in the bank rate. The weighted average rate of scheduled bank lending to the private sector, as stated earlier, was 4.21 per cent on December 30, 1958, but rose only to 4.96 per cent on June 30,1959 and to 5.14 per cent on December 31,1959 . The scheduled banks were, therefore, constrained to have positive free reserves.

The year 1960 presents an entirely different picture from that in 1959. Inspite of the higher bank rate in 1960 , the banks had negative free reserves. Their negative free reserves in 1960 were 2.6 per cent of their demand and time liabilities subject to reserve requirements (Table IV). In other words, their free reserves in 1960 were lower than in any previous year. Bank credit to the private sector increased at the rate of 27 per cent in 1960 and scheduled bank holdings of government securities declined by 6 per cent. Total bank credit increased at the rate of 12 per cent, i.e., 1 percentage point higher than in any previous year. If the bank rate were effective, it should have suppressed the rate of expansion of bank credit to the private sector even in 1960. But when private demand for credit recovered, the scheduled banks lent to the private sector much more and reduced their investments in government securities. In 1959, there was a shift to government securities in the portfolios of scheduled banks, but in 1960, there was a shift back to the private sector.

The question that may now be asked is that if the higher bank rate did not reduce the rate of expansion of bank credit, did it change its allocation among different sectors of the economy.

Table $\mathbf{V}$ gives the percentage distribution of scheduled bank advances between various sectors of the economy. In 1958, there was a significant 
TABLE IV

FREE RESERVES OF SGHEDULED BANKS IN PAKISTAN, 1954-1960

\begin{tabular}{lllcccccc}
\hline & 1 & & 2 & 3 & 4 & 5 & 6 \\
& Year & & $\begin{array}{c}\text { Excess } \\
\text { reserves }\end{array}$ & $\begin{array}{c}\text { Borrowings } \\
\text { from SBP }\end{array}$ & $\begin{array}{c}\text { Free } \\
\text { reserves }\end{array}$ & $\begin{array}{c}\text { Total } \\
\text { demand and } \\
\text { time } \\
\text { liabilities }\end{array}$ & $\begin{array}{c}\text { as }(\%) \\
(5)\end{array}$ \\
\hline 1954 & $\ldots$ & $\ldots$ & 42.1 & 51.0 & -8.9 & $1,704.0$ & -0.5 \\
1955 & $\ldots$ & $\ldots$ & 54.9 & 76.7 & -21.8 & $1,894.6$ & -1.2 \\
1956 & $\ldots$ & $\ldots$ & 75.2 & 94.9 & -19.7 & $2,098.3$ & -0.9 \\
1957 & $\ldots$ & $\ldots$ & 45.6 & 111.5 & -65.9 & $2,289.9$ & -3.0 \\
1958 & $\ldots$ & $\ldots$ & 72.5 & 100.1 & -27.6 & $2,584.9$ & -1.1 \\
1959 & $\ldots$ & $\ldots$ & 78.0 & 57.5 & +20.5 & $2,803.1$ & +0.7 \\
1960 & $\ldots$ & $\ldots$ & 36.7 & 122.4 & -85.7 & $3,241.9$ & -2.6 \\
\hline
\end{tabular}

Columns 2, 3, 4 and 5 are in million rupees and are annual averages of figures on $1_{\text {ast }}$ Friday of every month.

Earlier years have been omitted because data for Column 3 are not available.

Based on data from State Bank of Pakistan, State Bank Bulletins.

change in the allocation of bank credit to many sectors. But in 1959 (the year after the bank-rate change), there seems to be no significant change over 1958 except for the trend evident after 1955.

The share of commerce declined by about 4 percentage points in 1959 . But there has been a declining trend in the share of commerce after 1955 . Its share declined by an even greater magnitude in 1958 (by 12 per cent). The share of "services" seems to have increased significantly in 1959 (about 54 per cent of its 1958 level). But it increased significantly even in 1958 (by about 53 per cent of its level in 1957). Thus, if there is a change in the share of any sector after the bank-rate change, it seems less likely to be due to the increase in the bank rate and more likely to be due to factors already in operation before 1959.

We find that the borrowings of scheduled banks from the State Bank did decline but less than the increase in their reserves after the bank-rate change. The rate of interest charged by the scheduled banks on their loans to the public increased but gradually and slightly less than the increase in bank rate. The rate of increase of scheduled bank creait to the private sector dropped in 1959 after the increase in bank rate. This seems to be due less 
TABLE $V$

DISTRIBUTION OF SCHWDULED BANK CREDIT AMONG VARIOUS SECTORS OF THE PAKISTAN ECONOMY, 1955-1959 (percentages of total)

\begin{tabular}{|c|c|c|c|c|c|c|c|c|c|c|c|c|}
\hline & & & (1) & (2) & (3) & (4) & (5) & (6) & (7) & (8) & (9) & (10) \\
\hline Year & & & $\begin{array}{l}\text { Agriculture, } \\
\text { forestry, } \\
\text { hunting } \\
\text { and } \\
\text { fishing }\end{array}$ & $\begin{array}{l}\text { Mining } \\
\text { and } \\
\text { quarry. } \\
\text { ing }\end{array}$ & $\begin{array}{l}\text { Manufac- } \\
\text { turing }\end{array}$ & $\underset{\text { Construc- }}{\text { Cion }}$ & $\begin{array}{l}\text { Electricity, } \\
\text { gas, water } \\
\text { and } \\
\text { sanitary } \\
\text { services }\end{array}$ & Commerce & $\begin{array}{l}\text { Transport, } \\
\text { storage } \\
\text { and } \\
\text { communi- } \\
\text { cations }\end{array}$ & Services & Others & Total \\
\hline 1955 & $\ldots$ & ... & 1.68 & 0.72 & 22.54 & 3.00 & 2.00 & 59.00 & 1.47 & 6.53 & 3.05 & 100.00 \\
\hline 1957 & $\ldots$ & $\ldots$ & 1.33 & 0.53 & 30.78 & 1.05 & 0.43 & 59.71 & 0.83 & 2.62 & 2.72 & 100.00 \\
\hline 1958 & $\ldots$ & $\ldots$ & 3.12 & 0.26 & 35.45 & 1.29 & 0.37 & 47.85 & 1.06 & 4.53 & 6.07 & 100.00 \\
\hline 1959 & $\ldots$ & $\ldots$ & 4.18 & 0.62 & 34.14 & 1.36 & 0.33 & 43.60 & 1.18 & 8.40 & 6.45 & 100.00 \\
\hline
\end{tabular}

Data represent averages of quarterly figures based on data from State Bank of Pakistan, State Bank Bulletins. 
to the decrease in the supply of credit and more to a decrease in the demand for credit. In 1960, inspite of the higher bank rate, bank credit to the private sector expanded significantly. The rate of increase of scheduled bank investments in government securities was significantly higher in 1959 compared to the average of the previous five years even when the average yield on government securities was less than the bank rate in 1959. In 1960, scheduled bank holdings of government securities declined. Rate of expansion of total bank credit to both the private and the government sectors did not decline in 1959 and rose a little in 1960. We may, therefore, conclude that the bank rate was not effective in bringing about the desired results.

In view of this one performance of the bank rate instrument in Pakistan, can something be said about how effective the bank rate instrument may be in future as an instrument of credit control in the country? An attempt is made to lay down some conditions under which it may be effective.

A rise in the bank rate may be effective if: (a) price of government securities is allowed to fall to prevent banks from selling their securities to the State Bank in order to expand credit to the private sector offering a higher yield; $(b)$ new issues of government securities offer a higher rate of interest to make government securities attractive for scheduled banks.

A capital loss on securities may discourage scheduled banks from unloading their securities portfolio at the State Bank in order to expand loans to the private sector. It has been shown earlier than in 1960 the scheduled banks did decrease their holdings of government securities by 6 per cent ${ }^{9}$ and expanded their credit to the private sector by 27 per cent partly because price of securities was pegged and yield on loans to the private sector was higher. But if the price of government securities is not pegged, they lose their attractiveness as liquid assets. Scheduled banks may then not be willing to subscribe to new issues of government loans, because of fear of capital loss in view of the increasing demand for credit and gradually rising rates of interest for preventing inflation. In such a circumstance, the government will be constrained to sell new issues to the State Bank. This will be relatively more inflationary than selling securities to the scheduled banks.

With a rise in market rates of interest due to a higher bank rate, the government will have to raise the rate of interest on new issues of government securities to make these attractive to the scheduled banks 10 . If this

9. Some of these securities may have been sold to the State Bank while others may have matured. However, if some securities matured, it shows that the banks did not go for other issues with the proceeds, because the yield on government securities was not sufficiently attractive compared to the yield on private loans.

1). In Pakistan, the Central and the Provincial Governments did raise the rate of interests to 4 and 4.50 per cent respectively on new issues after the rise in the bank rate. 
is not done, private credit will be more attractive for banks because of a higher yield and also because of possibilities of capital loss on government securities in the event their price is allowed to fall. If the rate of interest is raised on government securities the interest burden of new public debt will rise and, therefore, the cost of governments' contribution to capital formation will also increase. 